\title{
Fiscal Policy and Economic Stability: A Case of Pakistan
}

\author{
Farhan Ahmed ${ }^{1}$; Suman Talreja²; Yasir Aman³*; Govinda Lohana ${ }^{4}$ \\ 1) NED University of Engineering \& Technology, Karachi-Pakistan \\ 2) SZABIST, Karachi-Pakistan \\ 3) Habib Bank Limited, Karachi-Pakistan \\ 4) Bank Al Habib Limited, Karachi-Pakistan
}

*Correspondence author email: agm.ird@yahoo.com

\begin{abstract}
This paper aims to assess the impact of fiscal policy on the economic stability within Pakistan. The findings indicate that the fiscal policy process constitutes the subsequent impact on the GDP, FDI, discount rate and CPI. That is to say, the corresponding expansionary and contractionary fiscal process has a direct and significant impact on the overall productivity, the foreign investment, the interest rates and the inflation process of the state. However, in comparison to these three variables, the exchange rate has an indirect impact and is lesser significant as compared to the other variables. The findings help stakeholders to understand how the overall fiscal policy affects the economic and business cycle of the country and how each individual is affected by the decisions made by the government executives in constituting the fiscal policy.
\end{abstract}

Keywords: Discount Rate, Gross Domestic Product, Exchange Rate

JEL Classification: O40, E62

\section{INTRODUCTION}

Fiscal Policy plays a very important and critical role in a nation's economy. It summarizes the sources of income of the state and their subsequent expenditures and based on that, the budget analysis is comprehended. Therefore, it is very important to know the microeconomic as well as the macroeconomic effects of the fiscal policy. However, our research would particularly comprise of the macroeconomic effects. The major macroeconomic variables that have a significant impact on fiscal policy include the total composition of output or GDP, the tax policy, the state expenditures, inflation rate, capital inflow or FDI, interest rates, inflation rates, and the exchange rates. Since these variables also reflect the development of our nation's economy, therefore it would also provide us a valuable insight as to how the economy is shaped and analyzed.

The fiscal policy is one of the important tools used by Government to give country a right direction. Government has two ways to change its direction by making adjustments in taxes or expenditures. Fiscal policy is the issue being discussed by the policy maker and researchers because it gives a right direction towards countries development. Serfraz \& Anwar (2009) stated Fiscal budget is overall changes in the government budget which impacts on macroeconomic variables such as GDP, unemployment, and inflation.

The main purpose of the fiscal policy is to generate the revenue stream in the form of taxes and those taxes are utilized to carry out the government expenditures. Government collect taxes in various forms such as sales tax, income tax, corporate tax, 
social security tax, and other indirect taxes Khalid et al., (2008). Government uses these revenues to meet its expenses such as infrastructure development, health care development, improving the standard of education etc. If Government expenditures are greater than its revenues, then it constitutes budget deficit and if its income exceeds the expenditures, than we have the budget surplus. The government can achieve the budget surplus in many ways. However, the government needs to constitute a clear and transparent policy under which it can improve the budgetary constraints and difficulties.

The fiscal policy has been seen as an important indicator to attract the foreign direct investment. For example, it can be used in a way that the government can reduce the corporate tax rates to attract the foreign investors. In this way, the lower cost for the investor with forecasting for high returns will encourage him to invest in various forms Li \& Resnick (2003). However, when industries grow, the employment rate also increases. The labor gets sufficient wages to have a stable life.

Fiscal policy affects the whole economy as it has the power to increase or reduce the output. Economy can be stabilized by saving money from the budget and invest in the better infrastructure for attracting the foreign direct investment. But if the Government is in deficit position and they have more expenditures then savings, then the Government can borrow short term and long term loans from the financial institutions like banks and corporations in the form of T-Bills and PIBs. In order to analyze its effects on the economy, we have to analyze both situations separately for short run and long run. In the long run, it contributes negatively towards our economy as it is considered a burden because, at the end of the period, we have to repay the interest and the principal amount both, which will, in turn, enhance and increase the budget deficit. However, in the short run, a situation named as Crowding-out Effect, this situation arises when the government relies on borrowings and utilizes the loans to build and improve the government-owned entities like health care and infrastructure development. Thus lesser loans are available for the private sector to carry out their work activities. Thus, the government is believed to be crowding out the private sector. This will, in turn, lead to higher interest rates in the future.

When the government collects less taxes and spending is in excess, then it means the government has initiated the Expansionary Fiscal Policy. The reduced taxes increase the consumption level of the people. However, the more consumption will increase the demand for goods. That includes both types of good, i.e. locally produced goods and imported goods. Due to the higher demand, the import of goods also increases, which in turn, increases the import bill. That means more dollars are going out of the economy and that constitutes the depreciation of the local currency. Another situation arises when the government borrows excessively. In this case, the interest rates increase. The higher interest rate will increase the capital inflow and will attract the foreign direct investment, which will, in turn, bring in more dollars into the economy. This constitutes the appreciation of local currency.

The main aim of this research is to analyze how each of the macroeconomic factors affects the fiscal policy process of the country. The research will also help us understand the importance of each of the subsequent factors. Fiscal Policy is of two types: namely contractionary fiscal policy and Expansionary Fiscal Policy. When the government revenues are greater than its expenses, then it constitutes the Contractionary Fiscal Policy. This means the budget is in surplus. And when the government expenditures are greater than its revenues, then it constitutes the Expansionary Fiscal Policy. This means the budget is in deficit. However, the traditional practice is that the State Bank uses the expansionary fiscal policy in tough times like recessions so that 
they could attract foreign direct investment and improve the capital structure of the country. The State Bank uses the contractionary policy in good economic times, i.e. when the economy is in boom. The main aim is to control the rising inflationary trends.

The objective of the study is to analyze the impact of macroeconomic effects on fiscal policy using the Vector Autoregression (VAR) Model. How each of the factors affects the composition of budget and the corresponding positive and negative relations will be studied. The variables that have been taken into account include the composition of output or GDP, the impact on exchange rates and the relation between the monetary policy and the fiscal policy which includes the impact of fiscal policy on the long-term interest rates of the country. The timeline of the study will be from 1995 to 2014 (20 years). The components of the VAR model included the exchange rate volatilities and level of GDP and the corresponding level of interest rates.

The study has an utmost importance since it determines the importance of each variable and how it brings about a significant change in the fiscal policy process. To analyze the impact each macroeconomic factor will create in the fiscal policy will help us determine the forces that play a critical role in devising the tax policy and the government expenditure and budgeting purposes. The main stakeholders of the study are: 1) The policymakers who would be able to determine how the tax policy will affect the overall economic activity of the country; 2) The economists who will help in devising a favorable fiscal policy that should strengthen the overall economy of the country; 3) The financial analysts who determine the level of interest rates based on the corresponding tax policies and economic conditions; 4) The general public who are the major taxpayers and what affect the fiscal policy brings into their financial positions.

\section{LITERATURE REVIEW OF THE STUDY}

In Pakistan, government stakeholders and economists are more focused and concerned about the monetary policy. However, it is also essential to look into the impact of fiscal policy in our economy. Economists, policymakers and financial analysts have different views about the impact of monetary and fiscal policy in our economy. In our research, we are focusing in detail on the impact of fiscal policy based on previous researches.

Fiscal policy determines the overall budget of the country in every corresponding year. And that budget contains the results of various variables like GDP or output and foreign inflows etc Favero \& Giavazzi (2007). Therefore, in order to analyze the impact of each macroeconomic variable, it is very important to have an insight related to the previous studies and researches that have been conducted on this particular course of study. Our literature would consist of studies from various regions and by various economists and analysts. This would help us in consolidating our research and for comparison purposes also. It is essential that the studies should be concerned with diversifying regions and capacities so that we may be able to summarize the overall or average impact of each macroeconomic variable on the fiscal policy of Pakistan.

Fiscal policy has a direct impact on the overall output of the country. Like if the government plans to increase the taxes, so this will lower the saving patterns of people and the consumption would also decrease. This will lower demand for goods and the overall productivity decreases. However, on the other side, the government can play a major role in increasing output by reducing taxes. The lower taxes would encourage saving patterns and will increase the consumption over a period of time. This will encourage more productivity and output and thus the GDP increases. Lower taxes also 
attract the foreign investors as they have a traditional view of investing in a state where growth and return opportunities are higher and taxes are lower.

\section{Fiscal Policy and GDP}

Fiscal policy determines the level of productivity and output. In the case where the state reduces taxes, the economy prospers as the output increases, the inflation decreases, employment increases and subsequently the overall business cycle is in a positive state. The taxes will bring in more capital inflow and it can also enhance the export bill and the trade deficit can also be reduced. This state not only provides a support to the trade but also the credit rating of the economy can be improved. The higher employment will discourage the people from finding employment opportunities abroad and the brain drain will be discouraged. Most of the times the state has been in a budget deficit position where the taxes are lower than the expenses. The main hurdle to this is the fact that the government seems reluctant to cut down on the state expenses. The traditional approach has always been to increase taxes to control the deficit.

According to Sandro et al., (2008), economic activity is positively affected by shocks to government purchases of goods and services, these shocks tends to increase private real GDP, however, the response after few years drop to zero. They further revealed that employment, private consumption, and investment also have positive effect.

The fiscal policy of the economy will determine the impact of the future economic indicators. We have been witnessing a trend of rising state expenses and it is rising at an increasing rate. The tax policy is unclear. It has been evident that a rising population of the nation does not pay taxes and that is also one cause of the budget deficit. However, the state executives usually abuse the power and seem reluctant in paying taxes Kneller et al., (1999).

\section{Fiscal Policy and Interest Rates}

The trend shows that the fiscal deficit has always resulted in an increase in the interest rate structure of the economy. The reason being that the higher state expenditures encourages more borrowing from the Central Bank. This will, in turn, affect the business cycle of the economy. The financial institutions will then be discouraged to borrow and thus the lending of banks will also get affected. Besides, the foreign investors will be reluctant to invest considering the too much cost in the form of corporate tax. Agha \& Khan (2006) argued in their study that long-run inflation is related to financing fiscal deficit as well as fiscal imbalances, by assuming impact of exchange rate and real GDP as exogenous.

The borrowing has a negative implication as it will also demotivate the investors that the country is indebted with too much money and the state is not in a stable economic position. The rising expenses and the rising deficit might force the economy to move towards foreign funding as the deficit also impacts the exchange rate and the local currency gets depreciated. The funding from the external agencies will have an adverse effect on the credit rating of the economy. The low rating puts the economy in an undesirable situation as no venture will come and invest in such economy. Therefore the fiscal policy process has a very significant impact on the discount rates of the country as it will determine the future economic position of the country. In this scenario, the monetary policy and the fiscal policy makers have a joint discussion as to how the economy can be stabilized and how the economic and financial position of the country can be improved. 


\section{Fiscal Policy and Inflation}

According to classical theory (Quantity Theory of Money), Money growth drive inflation, as higher growth rate of money determines the level of price. Fiscal policy has a direct impact on the inflationary trends in the country. The rise in the prices of goods and services occur when there is lesser output produced and more demand of goods is there. However, the lesser output is a result of lesser industries operating in the economy or the lesser factors of production Shahid Ali \& Naveed Ahmed (2010). The lesser industries are a result of dissatisfaction of the industries and investors that withdraw their capital from the country.

António \& Peter (2007), discussed that "fiscal slippages are mainly due to reversals in tax policies", which in contrast tends to worsen economic conditions with rise in deficit. However, in good time bad policies result as contributing factor in aggregate macroeconomic instability.

The investors are generally concerned with high return and low cost. But due to the corporate tax rates, the profit structure of the industries get affected which results in closure or bankruptcy. The inflation decreases the saving patterns of the people and results in lesser investments. However, due to higher inflation, poverty rises and the lifestyle of the people gets affected as the inelastic goods become costly and people could not meet with the rising prices of goods. In this situation, the brain drain can also occur where the educated class feels the need to getting employed abroad for better income and to meet up the expenses.

\section{Fiscal Policy and Exchange Rates}

The fiscal policy can affect the exchange rates in a way that if the state has implemented an expansionary fiscal policy, then the rising government spending will result in the higher interest rates. The higher interest rates are being seen by the foreign investors as an opportunity to invest in a higher return. They invest in the form of dollars, the supply of the dollar currency increases. Thus the local currency appreciates and the imported goods become cheaper. The higher supply of dollar will not only decrease the import bill but will also generate much revenue through the exports which will become expensive for the buyers. Therefore, the fiscal policy has a much greater say when it comes to improving the status of the local currency and strengthening the trade balance of the country. The exchange rates are also seen by some investors as a strong indicator of the economic performance of the country. Agha \& Khan (2006) argued in their study that long-run inflation is related to financing fiscal deficit as well as fiscal imbalances, by assuming impact of exchange rate and real GDP as exogenous.

The appreciation of the local currency indicates that the trade balances of the country are in a stable position due to the cheaper imports and the inflationary trends in the country is also controlled.

\section{Fiscal Policy and FDI}

Foreign direct investment is a critical variable which determines the overall economic stability and strength of the country. The FDI can be raised in the expansionary fiscal policy in which the interest rates are high. FDI inflows help to reduce transaction cost and risk for foreign investors and help to improve more credible property rights protection Li \& Resnick (2003).

Also, there is one thing that should be taken into account is the fact that the rising tax policy has a negative impact on the FDI. If the corporate tax rate would be high, then it will affect the financial position of the firms as the profits will be squeezed. However, in this situation, most firms opt for capital expansion in the form of debt so 
that the interest acts as a shield from rising tax rate. Makki \& Somwaru (2004), their findings suggested that FDI and economic growth trade has strong positive integration for developing economies. They further discussed that domestic investments are stimulated by FDI and its contribution towards growth of economy is enhanced by its positive integration with stability of institutions and macroeconomic policies. Therefore, it can be said that the expansionary fiscal policy can encourage the foreign investment and the government shall take measures to improve the tax policy to be in a strong economic state

\section{Theoretical Review}

There have been studies and researches conducted on this study and there are various schools of thoughts that have a different views on the impact of each variable on the fiscal policy. Below are the summarized views of the studies:

Antonio Afonso and Ricardo M.Sousa (2009) concluded the results by using the Vector Autoregression Model (VAR). He stated that the expansionary fiscal policy has a minor impact on the private sector. The rise in the state expenses has an indirect impact on the overall output and GDP. He further stated that the high government spending gives rise to the decline of the stock exchange and the stock prices fall.

Fata's and Mihov (2001) studied the fiscal policy process in detail and concluded that the fiscal policy and monetary policy have a strong relation and that both must be devised keeping in mind the state-owned as well as the private sector. However, he was of the view that the private sector is usually ignored when devising the fiscal policy. The government will usually focus more on the tax policy structure and less on the state expenditures

Blanchard and Perotti (2002) studied the impact of elastic goods in times of contractionary fiscal policy. The contractionary fiscal policy arises when the taxes are increased and the expenses are controlled. This is mainly done to have a strong budgetary position and the prices of elastic goods rise due to the lesser inflationary scenarios in the concerned fiscal policy. Normally economists and financial analysts are more concerned and focused on the impact of monetary policy than fiscal policy. In impact of monetary policy, it is related to interest that's why it is directly hurting the money supply and cost of interest. Whereas in fiscal policy it is not the case.

Other studies have been conducted which stated that the high-worth investors are of the view that the privately-owned corporations and institutions are earning them a higher rate of return than the state-owned enterprises. The major reason for this could be the highly sophisticated check-and-balance system in the private sector as opposed to the state-owned companies. The state needs to have sufficient funds to run and operate the enterprises and that is possible only when the state needs to plan and control its flow of funds. It is highly critical in the fiscal policy systems that the government needs to control its expenditures up to the extent that they should achieve a positive balance of payments situation. This is possible when the states plans the tax and expenditure policy and implement it accordingly.

Considering the capital-intensive technologies, the positive balance-of-payments situation will help them create factories and highly profitable institutions from which a considerable source of income is generated. Therefore, studying the impact of each macroeconomic variable will help us understand how each of the fiscal policy variables affects it in a positive or negative way. Lowering the expenditures and stabilizing the tax policy is also not good as it will cease the development process of the country. 


\section{METHODS}

The research would be based on a detailed analysis on the fiscal policy of Pakistan. The data can be collected through multiple sources which include the publications, the past researches and online website etc. The scope of this study will be meaningful to all the government officials, policy makers, economists, financial analysts and decision makers in strategic business issues. The data will be gathered for 20 years, i.e. 1996-2014 and thus this data can be used to analyze the effect the tax policy brings in to the economy. Besides the tax policy, the impact of the high rise in the government expenses over the past few years will also be studied. For this purpose, the concerned persons will be approached and communicated face to face and via email.

The figure above shows the theoretical framework of our research study. As we have discussed before, we will be using the multiple macroeconomic variables in order to evaluate and analyze the results of each variable on the fiscal policy. Tax policy and government expenditures have been defined as the dependent variables as they constitute the fiscal policy whereas the GDP, FDI, CPI, Discount rate and the Exchange rate act as the independent variables.

We will be using the Multiple Regression Models for the research study. The probability of each variable can be interpreted by the unit root test. If the data does not come out as stationary, then it will tested at $1^{\text {st }}$ difference interval to make it consistent. Then Vector Autoregression (VAR) Model will be used to analyze the impact of each variable against the corresponding variables and thus the results will be comprehended. Florian Hoppner (2001), Khan et al (2007) \& Sandro \& Roberto (2008) use same model in their research study to analyze the data.

We aim to conclude the output by analyzing the impact of the fiscal policy process on each of the corresponding dependent and independent variables.

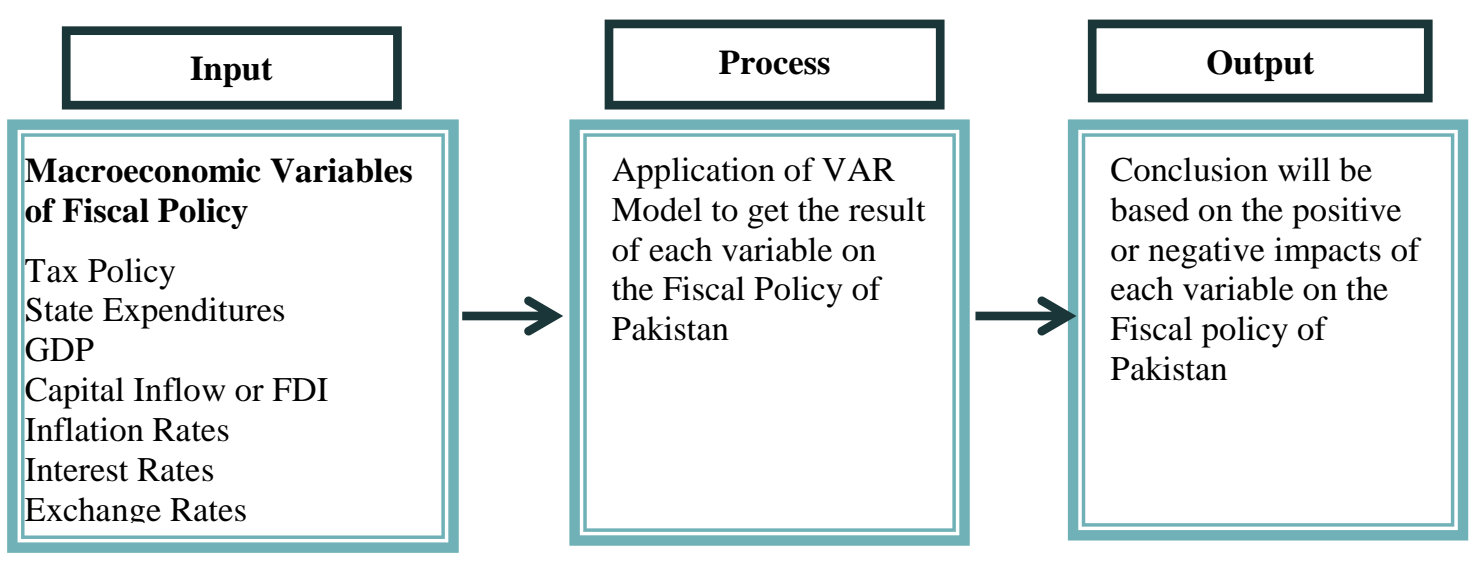

Throughout the literature review, we have observed that the independent variables like GDP, interest rates have a significant impact on the fiscal policy but to further strengthen our study we have used the Multiple Linear Regression to capture the output. We have used the f-test and its p-value. The f-test is an important tool for testing the joint significance of all the independent variables. If all the independent variables are not jointly significant, then we cannot reject the null hypothesis and homoskedasticity will be assumed. To reject a null hypothesis, we require a p-value less than 0.05 . Since the p-values of all our independent variables is less than 0.05 , therefore it can be concluded that homoskedasticity is present. Which means each independent variable has an equal significance and impact to the dependent variable. We have performed the unit-root test to conclude the output. 
The unit root test is basically conducted to test whether a time series variable is non-stationary or not. To test the validity of the unit root test, we have the Augmented Dickey-Fuller (ADF) test developed by David Dickey and Wayne Fuller in 1979. It takes into account the f-statistic and its p-value which shows either the null hypothesis is rejected or not. Since the p-value of all the variables that we have taken into account is less than 0.05 , therefore it can be concluded that the 20 years of data is stationary and lesser variation can be seen over the period of time. However, initially the data was nonstationary while using the unit root test but after capturing the data at $1^{\text {st }}$ difference interval, it can be seen that the data is stationary and there is no major fluctuation in the data over the entire period. It is highly critical to validate the data with tests so that accurate results can be captured.

In this case, the null hypothesis is the unit root which we have tested through Augmented Dickey-Fuller (ADF) test. The results have become static which means that the VAR model can be applied to capture the accurate results.

\section{RESULTS AND DISCUSSION}

We have used the VAR Model to validate and analyze the impact and interrelation of each of our dependent and independent variables. As shown in Table 8, we have analyzed each independent variable with the other independent variable and likewise with the dependent variable too. So it will give us the impact of each variable and we will get to know their dependency over each other. We have captured the data on the $1 \%$ difference interval as well as at $2 \%$ difference interval as shown in the tables above.

As shown in Table 1 (Appendix), the results were initially extracted through the unit root test and it indicated that the CPI has a probability of 0.0012 which accepts the null hypothesis that the data has not been consistence over the years. However, after conducting tests at 2\% difference interval (See Table 9 in Appendix), it showed a consistent result and it can be deduced that the inflation has a direct and significant impact on the other variables and it has an adverse impact on the foreign direct investment which show a heavy reliance at $1 \%$ difference interval. The probability of CPI stands at 0.7035 (See Table 9 in Appendix). It can be concluded that the inflation has major impact on the fiscal policy as it has around $70 \%$ impact on the government expenditures and $94 \%$ impact on the Government revenues. Besides, it has a major impact on the discount rate since the monetary and fiscal policies go together. Therefore, the determinants of both these policies determine the corresponding inflation and interest rates. Catao and Terrones (2003) revealed a positive relationship among inflation and fiscal deficit between developing countries and high inflation country groups, but as far as advanced economies with low inflation are concerned results are not same.

It can be further deduced from the VAR model (See Table 8 in Appendix) that the discount rate has a greater impact on the Exchange Rate (Around 94\% at 1\% difference interval). The reason being that when the taxes are raised, the discount rate also tends to increase as the government borrowing also increases to control the budget deficit. Therefore, in case of high government borrowing, the foreign investors become hesitant to invest, which means lesser dollar is flowing into the economy. The demand for dollar is already high due to imports. Therefore, the more demand and lesser supply of dollar will result in the appreciation of the foreign currency and subsequently, the local currency depreciates. 
Furthermore, when the taxes are raised, keeping in mind the corporate tax rate, the investors are reluctant to invest due to higher tax cost. In the expansionary fiscal policy where the taxes are reduced and the government spending is raised, we see a trend of higher interest rates or discount rates to discourage borrowing at any level. In this situation, the Central bank raises interest rates of the economy which can attract the foreign investors to invest at high rate. However, we have witnessed over the past few years that the rising tax policy has decreased the overall output and productivity of the economy (See Table 8 in Appendix). This happens due to the fact that the industries need to cope with the higher tax rates and closure of industries take place. The lesser output will be produced which then constitute a rising inflation in the future. Mountford (2005), found nearly similar results stating that tax cut helps to improve GDP.

However, the impact of foreign direct investment can also be deduced from the Model. When investors bring in money into the economy, then that means more dollar currency is flowing into the economy which appreciates the local currency of the nation. The exchange rate difference becomes lower between rupee and dollar (See Table 8 in Appendix) However in times of expansionary fiscal policy, the spending is high and government borrowing is high. This means more borrowing take place. When the economy has more borrowing, then there comes a point where we feel the need to borrow from external sources. This means more dollars move out of the economy and the depreciation of local currency takes place. The high reliance on external agencies will have an adverse effect on the FDI.

\section{CONCLUSION AND RECOMMENDATIONS}

The results portray that the macroeconomic variables have a major inter-relation among each other. No macroeconomic variable can be ignored. The fiscal policy shall be devised keeping in mind all the variables. However, the past trend shows that the country has been in the deficits for most period of time. This is due to the heavy reliance on debt and lesser output and productivity due to lack of resources like electricity and gas supply. The fiscal policy has a key role in improving the economic position of the country. The fiscal policies can either improve or damage the economy of the country. Therefore, keeping in mind the current scenario of the country, it is the need of the hour that the country shall move into strict measures in improving the tax policy of the country and to reduce the country's expenses up to the level where they can achieve the budget surplus. The fiscal policy plays a critical role in the economic stability of the country. Therefore, it shall be improved and the budgetary constraints shall be reduced. In this way, the economy can grow and the country can prosper.

The government should take measures to strengthen the tax policy and the tax laws. The tax system is corrupted which needs to be taken care of. The tax collection process shall be transparent. However, in the current scenario of high budget deficit, the government shall discontinue providing subsidies, and move towards controlling the state expenses. This will have a positive impact on the fiscal position of the country. When the budget surplus occurs, the government needs to utilize that surplus to control the other economic deficits like trade deficit. The local currency has been adversely depreciated over a period of time due to higher external debt. It can be reduced by achieving self-sufficiency, by increasing the output level, strengthen the capital position of the country by encouraging the foreign investors and by stabilizing the interest rates in favor of the positive economic trend.

Further studies can be conducted where the fiscal policy can be analyzed through the performance of the key stakeholders' firms and financial institutions of the country. 
Besides the impact of nationalization and privatization on fiscal policy can also be studied. The privatization is believed to be more productive and output levels are higher so how it will impact the fiscal policy process is also something that needs to be analyzed and researched. Fiscal policy can also be analyzed based on the performance of the equity market of the economy. That is to say, how the booming stock exchange impacts the fiscal policy process and vice versa.

\section{REFERENCES}

Afonso, António \& Claeys, Peter (2007). "The dynamic behavior of budget components and output," Working Paper Series 0775, European Central Bank.

Agha, A. I., \& Khan, M. S. (2006). An empirical analysis of fiscal imbalances and inflation in Pakistan. SBP Research Bulletin, 2(2), 343-362.

Alesina, A \& R Perotti (1995). "Fiscal Expansions and Fiscal Adjustments in OECD Countries," NBER Working Papers 5214, August, National Bureau of Economic Research

Carlos Marinheiro (1998)," The Stability Pact and the Portuguese Fiscal Policy: the application of a VAR Model", Faculty of Economics, University of Coimbra

Catao, L. and E.M. Terrones (2003). Fiscal Deficits and Inflation. IMF Working Paper WP/03/65.washington, D.C.

Dario Caldara, Christophe Kamps (2008), "What are the effects of Fiscal Policy Shocks? A VAR Based Comparative Analysis", European Central Bank, Working Paper Series

Devarajan, S., Swaroop, V., \& Zou, H.-f. (1996), "The Composition of Public Expenditure and Economic Growth", Journal of Monetary Economics, Vol. 37, pp. 313-344.

Easterly, W., \& Rebelo, S. (1993), "Fiscal policy and economic growth: An empirical investigation", Journal of Monetary Economics, Vol. 32, pp. 417-458. http://www.nber.org/papers/w4499

Favero, C and F Giavazzi (2007), "Debt and the effects of fiscal policy", NBER Working Paper 12822, January, pp 26.

Florian Hoppner (2001), "A VAR Analysis on the Effects of Fiscal Policy in Germany", Institute for International Economics, University of Bonn,

Fowlie, K (1999), “Automatic fiscal stabilizers”, Treasury Working Paper 99/7, 15.

Giavazzi, Francesco \& Pagano, Marco (1990). "Can Severe Fiscal Contractions Be Expansionary? Tales of Two Small European Countries," CEPR Discussion Papers 417, C.E.P.R. Discussion Papers.

Kneebone, R. D., \& McKenzie, K. J. (1999), "The Characteristics of Fiscal Policy in Canada", Canadian Public Policy, Vol. 25 No. 4, pp. 483-501.

Kneller, R., Bleaney, M. F., \& Gemmell, N. (1999), "Fiscal policy and growth: evidence from OECD countries", Journal of Public Economics, Vol. 74, pp. 171-190.

Li, Q., \& Resnick, A. (2003). Reversal of fortunes: Democratic institutions and foreign direct investment inflows to developing countries. International organization, 57(1), 175-211.

Makki, S. S., \& Somwaru, A. (2004). Impact of foreign direct investment and trade on economic growth: Evidence from developing countries. American Journal of Agricultural Economics, 86(3), 795-801.

Mountford, A.; Uhlig, H. (2005), "What are the effects of fiscal policy shocks?" Humboldt-Universität zu Berlin Working Paper SFB No. 649. 
Perotti, R. (1999), "Fiscal policy in good times and bad", Quarterly Journal of Economics, 114, 1399-1436.

Roberto Perotti (2004). "Estimating the effects of fiscal policy in OECD countries," Working Papers 276, IGIER (Innocenzo Gasparini Institute for Economic Research), Bocconi University.

Sandro, Raffaela, Stefano and Roberto (2008), "The Effects of Fiscal Policy in Italy: Evidence from a VAR Model", Social Science Research Network Papers,

Sarfraz, A., \& Anwar, M. (2009). Fiscal Imbalances and Inflation: A Case Study of Pakistan. Pakistan journal of social sciences (PJSS), 29(1).

Shahid Ali and Naved Ahmad (2010), "The Effects of Fiscal Policy on Economic Growth: Empirical Evidences Based on Time Series Data from Pakistan", the Pakistan Development Review Paper 49:4 Part 2, pp 497-512. 


\section{APPENDIX}

\section{Table 1. Unit Root Test of CPI}

Null Hypothesis: D(LNCPI,2) has a unit root

Exogenous: Constant

Lag Length: 0 (Automatic based on SIC, MAXLAG=4)

\begin{tabular}{lccl}
\hline & & t-Statistic & Prob.* \\
\hline \multicolumn{2}{l}{ Augmented Dickey-Fuller test statistic } & -4.975471 & 0.0012 \\
\hline Test critical values: & 1\% level & -3.886751 & \\
& $5 \%$ level & -3.052169 & \\
& $10 \%$ level & -2.666593 & \\
\hline
\end{tabular}

*MacKinnon (1996) one-sided p-values.

Warning: Probabilities and critical values calculated for 20

observations and may not be accurate for a sample size of 17

Augmented Dickey-Fuller Test Equation

Dependent Variable: D(LNCPI,3)

Method: Least Squares

Sample (adjusted): 420

Included observations: 17 after adjustments

\begin{tabular}{lllll}
\hline \hline Variable & Coefficient & Std. Error & t-Statistic & Prob. \\
\hline \hline D(LNCPI(-1),2) & -1.242833 & 0.249792 & -4.975471 & 0.0002 \\
C & -0.002605 & 0.008937 & -0.291478 & 0.7747 \\
\hline R-squared & 0.622692 & Mean dependent var & -0.000807 \\
Adjusted R-squared & 0.597538 & S.D. dependent var & 0.058039 \\
S.E. of regression & 0.036820 & Akaike info criterion & -3.655437 \\
Sum squared resid & 0.020335 & Schwarz criterion & -3.557412 \\
Log-likelihood & 33.07122 & F-statistic & 24.75531 \\
Durbin-Watson stat & 1.889379 & Prob(F-statistic) & 0.000166 \\
\hline
\end{tabular}




\section{Table 2. Unit Root Test of Discount Rate}

Null Hypothesis: D(LNDR) has a unit root

Exogenous: Constant

Lag Length: 0 (Automatic based on SIC, MAXLAG=4)

\begin{tabular}{lccc}
\hline \hline & & t-Statistic & Prob.* \\
\hline \hline Augmented Dickey-Fuller test statistic & -4.078753 & 0.0064 \\
\hline Test critical values: & 1\% level & -3.857386 & \\
& 5\% level & -3.040391 & \\
& 10\% level & -2.660551 & \\
\hline
\end{tabular}

*MacKinnon (1996) one-sided p-values.

Warning: Probabilities and critical values calculated for 20

observations and may not be accurate for a sample size of 18

Augmented Dickey-Fuller Test Equation

Dependent Variable: D(LNDR,2)

Method: Least Squares

Sample (adjusted): 320

Included observations: 18 after adjustments

\begin{tabular}{lllll}
\hline \hline Variable & Coefficient & Std. Error & t-Statistic & Prob. \\
\hline \hline D(LNDR(-1)) & -0.983999 & 0.241250 & -4.078753 & 0.0009 \\
C & -0.040886 & 0.043446 & -0.941073 & 0.3607 \\
\hline R-squared & 0.509747 & Mean dependent var & -0.011878 \\
Adjusted R-squared & 0.479106 & S.D. dependent var & 0.251951 \\
S.E. of regression & 0.181841 & Akaike info criterion & -0.466933 \\
Sum squared resid & 0.529056 & Schwarz criterion & -0.368003 \\
Log-likelihood & 6.202401 & F-statistic & 16.63622 \\
Durbin-Watson stat & 1.947108 & Prob(F-statistic) & 0.000875 \\
\hline
\end{tabular}

Table 3. Unit Root Test of Exchange Rate

Null Hypothesis: D(LNER) has a unit root

Exogenous: Constant

Lag Length: 0 (Automatic based on SIC, MAXLAG=4)

\begin{tabular}{llll}
\hline \hline & & & \\
Augmented Dickey-Fuller test statistic & -2.760230 & Prob. ${ }^{*}$ \\
\hline Test critical values: & 1\% level & -3.857386 & \\
& $5 \%$ level & -3.040391 & \\
\hline
\end{tabular}

*MacKinnon (1996) one-sided p-values.

Warning: Probabilities and critical values calculated for 20

observations and may not be accurate for a sample size of 18

Augmented Dickey-Fuller Test Equation

Dependent Variable: D(LNER,2)

Method: Least Squares

Date: 11/06/15 Time: 19:01

Sample (adjusted): 320

Included observations: 18 after adjustments

\begin{tabular}{lllll}
\hline \hline Variable & Coefficient & Std. Error & t-Statistic & Prob. \\
\hline \hline D(LNER(-1)) & -0.641045 & 0.232243 & -2.760230 & 0.0139 \\
C & 0.033976 & 0.020554 & 1.653011 & 0.1178 \\
\hline R-squared & 0.322576 & Mean dependent var & -0.007578 \\
Adjusted R-squared & 0.280237 & S.D. dependent var & 0.069980 \\
S.E. of regression & 0.059371 & Akaike info criterion & -2.705596 \\
Sum squared resid & 0.056398 & Schwarz criterion & -2.606666 \\
Log-likelihood & 26.35037 & F-statistic & 7.618872 \\
Durbin-Watson stat & 1.819361 & Prob(F-statistic) & 0.013938 \\
\hline
\end{tabular}




\section{Table 4. Unit Root Test of FDI}

Null Hypothesis: D(LNFDI) has a unit root

Exogenous: Constant

Lag Length: 0 (Automatic based on SIC, MAXLAG=4)

\begin{tabular}{lccc}
\hline \hline & & t-Statistic & Prob. $^{*}$ \\
\hline \hline \multicolumn{2}{l}{ Augmented Dickey-Fuller test statistic } & -3.092181 & 0.0453 \\
\hline Test critical values: & 1\% level & -3.857386 & \\
& 5\% level & -3.040391 & \\
& $10 \%$ level & -2.660551 & \\
\hline
\end{tabular}

*MacKinnon (1996) one-sided p-values.

Warning: Probabilities and critical values calculated for 20

observations and may not be accurate for a sample size of 18

Augmented Dickey-Fuller Test Equation

Dependent Variable: D(LNFDI,2)

Method: Least Squares

Sample (adjusted): 320

Included observations: 18 after adjustments

\begin{tabular}{lllll}
\hline \hline Variable & Coefficient & Std. Error & t-Statistic & Prob. \\
\hline \hline D(LNFDI(-1)) & -0.688580 & 0.222684 & -3.092181 & 0.0070 \\
C & 0.064094 & 0.086808 & 0.738344 & 0.4710 \\
\hline R-squared & 0.374061 & Mean dependent var & 0.030278 \\
Adjusted R-squared & 0.334940 & S.D. dependent var & 0.448016 \\
S.E. of regression & 0.365363 & Akaike info criterion & 0.928588 \\
Sum squared resid & 2.135840 & Schwarz criterion & 1.027518 \\
Log-likelihood & -6.357288 & F-statistic & 9.561585 \\
Durbin-Watson stat & 2.053981 & Prob(F-statistic) & 0.006993 \\
\hline
\end{tabular}

\section{Table 5. Unit Root Test of GDP}

Null Hypothesis: D(LNGDP) has a unit root

Exogenous: Constant

Lag Length: 0 (Automatic based on SIC, MAXLAG=4)

\begin{tabular}{lccc}
\hline \hline & & t-Statistic & Prob. $^{*}$ \\
\hline \hline Augmented Dickey-Fuller test statistic & -4.282808 & 0.0042 \\
\hline Test critical values: & 1\% level & -3.857386 & \\
& $5 \%$ level & -3.040391 & \\
& $10 \%$ level & -2.660551 & \\
\hline
\end{tabular}

*MacKinnon (1996) one-sided p-values.

Warning: Probabilities and critical values calculated for 20

observations and may not be accurate for a sample size of 18

Augmented Dickey-Fuller Test Equation

Dependent Variable: D(LNGDP,2)

Method: Least Squares

Sample (adjusted): 320

Included observations: 18 after adjustments

\begin{tabular}{lllll}
\hline \hline Variable & Coefficient & Std. Error & t-Statistic & Prob. \\
\hline \hline D(LNGDP(-1)) & -1.064570 & 0.248568 & -4.282808 & 0.0006 \\
$\mathrm{C}$ & -0.022066 & 0.099234 & -0.222364 & 0.8268 \\
\hline R-squared & 0.534104 & Mean dependent var & 0.005907 \\
Adjusted R-squared & 0.504986 & S.D. dependent var & 0.597100 \\
S.E. of regression & 0.420103 & Akaike info criterion & 1.207805 \\
Sum squared resid & 2.823784 & Schwarz criterion & 1.306735 \\
Log-likelihood & -8.870248 & F-statistic & 18.34245 \\
Durbin-Watson stat & 1.980151 & Prob(F-statistic) & 0.000571 \\
\hline
\end{tabular}


Table 6. Unit Root Test of Government Expenditure

Null Hypothesis: D(LNGOVTEXP) has a unit root

Exogenous: Constant

Lag Length: 4 (Automatic based on SIC, MAXLAG=4)

\begin{tabular}{lccc}
\hline \hline & & t-Statistic & Prob. $^{*}$ \\
\hline \hline Augmented Dickey-Fuller test statistic & -3.411832 & 0.0289 \\
\hline Test critical values: & 1\% level & -4.004425 & \\
& 5\% level & -3.098896 & \\
& 10\% level & -2.690439 & \\
\hline
\end{tabular}

*MacKinnon (1996) one-sided p-values.

Augmented Dickey-Fuller Test Equation

Dependent Variable: D(LNGOVTEXP,2)

Method: Least Squares

Sample (adjusted): 720

Included observations: 14 after adjustments

\begin{tabular}{lllll}
\hline \hline Variable & Coefficient & Std. Error & t-Statistic & Prob. \\
\hline \hline D(LNGOVTEXP(-1)) & -3.140014 & 0.920331 & -3.411832 & 0.0092 \\
D(LNGOVTEXP(-1),2) & 2.250391 & 0.903566 & 2.490567 & 0.0375 \\
D(LNGOVTEXP(-2),2) & 1.865106 & 0.719255 & 2.593107 & 0.0320 \\
D(LNGOVTEXP(-3),2) & 1.468364 & 0.546288 & 2.687894 & 0.0276 \\
D(LNGOVTEXP(-4),2) & 1.311049 & 0.366042 & 3.581694 & 0.0072 \\
C & 0.235189 & 0.099693 & 2.359132 & 0.0460 \\
\hline R-squared & 0.793830 & Mean dependent var & 0.005441 \\
Adjusted R-squared & 0.664975 & S.D. dependent var & 0.546364 \\
S.E. of regression & 0.316243 & Akaike info criterion & 0.832916 \\
Sum squared resid & 0.800077 & Schwarz criterion & 1.106797 \\
Log-likelihood & 0.169591 & F-statistic & 6.160604 \\
Durbin-Watson stat & 2.613653 & Prob(F-statistic) & 0.012448 \\
\hline
\end{tabular}

\section{Table 7. Unit Root Test of Government Expenditure}

Null Hypothesis: D(LNGOVTREV) has a unit root

Exogenous: Constant

Lag Length: 4 (Automatic based on SIC, MAXLAG=4)

\begin{tabular}{lccc}
\hline \hline & & t-Statistic & Prob.* \\
\hline \hline \multicolumn{2}{c}{ Augmented Dickey-Fuller test statistic } & -3.890777 & 0.0123 \\
\hline Test critical values: & 1\% level & -4.004425 & \\
& 5\% level & -3.098896 & \\
& 10\% level & -2.690439 & \\
\hline
\end{tabular}

*MacKinnon (1996) one-sided p-values.

Augmented Dickey-Fuller Test Equation

Dependent Variable: D(LNGOVTREV,2)

Method: Least Squares

Sample (adjusted): 720

Included observations: 14 after adjustments

\begin{tabular}{lllll}
\hline Variable & Coefficient & Std. Error & t-Statistic & Prob. \\
\hline D(LNGOVTREV(-1)) & -3.236326 & 0.831794 & -3.890777 & 0.0046 \\
D(LNGOVTREV(-1),2) & 2.332220 & 0.827221 & 2.819343 & 0.0225 \\
D(LNGOVTREV(-2),2) & 2.040346 & 0.641738 & 3.179407 & 0.0130 \\
D(LNGOVTREV(-3),2) & 1.510029 & 0.512058 & 2.948945 & 0.0185 \\
D(LNGOVTREV(-4),2) & 1.488785 & 0.355056 & 4.193095 & 0.0030 \\
C & 0.258866 & 0.078709 & 3.288882 & 0.0110 \\
\hline R-squared & 0.855032 & Mean dependent var & -0.000943 \\
Adjusted R-squared & 0.764426 & S.D. dependent var & 0.427907 \\
S.E. of regression & 0.207689 & Akaike info criterion & -0.008026 \\
Sum squared resid & 0.345077 & Schwarz criterion & 0.265856 \\
Log-likelihood & 6.056182 & F-statistic & 9.436885 \\
Durbin-Watson stat & 2.601960 & Prob(F-statistic) & 0.003313 \\
\hline
\end{tabular}


Table 8. VAR Model

Vector Autoregression Estimates

Sample (adjusted): 320

Included observations: 18 after adjustments

Standard errors in ( ) \& t-statistics in [ ]

\begin{tabular}{|c|c|c|c|c|c|c|c|}
\hline & LNCPI & LNDR & LNER & LNFDI & LNGDP & LNGOVTEXP & LNGOVTREI \\
\hline LNCPI(-1) & $\begin{array}{l}0.425214 \\
(2.18342) \\
{[0.19475]}\end{array}$ & $\begin{array}{l}4.495219 \\
(7.60858) \\
{[0.59081]}\end{array}$ & $\begin{array}{l}-2.740858 \\
(2.13227) \\
{[-1.28542]}\end{array}$ & $\begin{array}{l}-27.68848 \\
(6.68528) \\
{[-4.14171]}\end{array}$ & $\begin{array}{l}0.704771 \\
(24.0696) \\
{[0.02928]}\end{array}$ & $\begin{array}{l}6.838769 \\
(19.9976) \\
{[0.34198]}\end{array}$ & $\begin{array}{l}2.878418 \\
(14.7530) \\
{[0.19511]}\end{array}$ \\
\hline LNCPI(-2) & $\begin{array}{l}0.781402 \\
(1.98198) \\
{[0.39425]}\end{array}$ & $\begin{array}{l}-1.548034 \\
(6.90661) \\
{[-0.22414]}\end{array}$ & $\begin{array}{l}2.944805 \\
(1.93554) \\
{[1.52144]}\end{array}$ & $\begin{array}{l}23.62826 \\
(6.06849) \\
{[3.89360]}\end{array}$ & $\begin{array}{l}3.662025 \\
(21.8489) \\
{[0.16761]}\end{array}$ & $\begin{array}{l}-3.319141 \\
(18.1526) \\
{[-0.18285]}\end{array}$ & $\begin{array}{l}0.597544 \\
(13.3919) \\
{[0.04462]}\end{array}$ \\
\hline $\operatorname{LNDR}(-1)$ & $\begin{array}{l}0.076066 \\
(0.16591) \\
{[0.45847]}\end{array}$ & $\begin{array}{l}-0.210758 \\
(0.57815) \\
{[-0.36454]}\end{array}$ & $\begin{array}{l}0.153785 \\
(0.16202) \\
{[0.94915]}\end{array}$ & $\begin{array}{l}-0.242056 \\
(0.50799) \\
{[-0.47649]}\end{array}$ & $\begin{array}{l}0.229336 \\
(1.82898) \\
{[0.12539]}\end{array}$ & $\begin{array}{l}-1.433755 \\
(1.51956) \\
{[-0.94353]}\end{array}$ & $\begin{array}{l}-0.647350 \\
(1.12104) \\
{[-0.57746]}\end{array}$ \\
\hline $\operatorname{LNDR}(-2)$ & $\begin{array}{l}0.023770 \\
(0.11138) \\
{[0.21341]}\end{array}$ & $\begin{array}{l}0.489163 \\
(0.38812) \\
{[1.26035]}\end{array}$ & $\begin{array}{l}-0.040847 \\
(0.10877) \\
{[-0.37554]}\end{array}$ & $\begin{array}{l}-1.435878 \\
(0.34102) \\
{[-4.21054]}\end{array}$ & $\begin{array}{l}-0.386316 \\
(1.22780) \\
{[-0.31464]}\end{array}$ & $\begin{array}{l}-0.787253 \\
(1.02009) \\
{[-0.77175]}\end{array}$ & $\begin{array}{l}-0.852610 \\
(0.75256) \\
{[-1.13295]}\end{array}$ \\
\hline $\operatorname{LNER}(-1)$ & $\begin{array}{l}0.235697 \\
(0.36279) \\
{[0.64968]}\end{array}$ & $\begin{array}{l}-0.152851 \\
(1.26421) \\
{[-0.12091]}\end{array}$ & $\begin{array}{l}0.737714 \\
(0.35429) \\
{[2.08224]}\end{array}$ & $\begin{array}{l}5.204768 \\
(1.11080) \\
{[4.68562]}\end{array}$ & $\begin{array}{l}1.194543 \\
(3.99930) \\
{[0.29869]}\end{array}$ & $\begin{array}{l}-1.051839 \\
(3.32271) \\
{[-0.31656]}\end{array}$ & $\begin{array}{l}-0.483769 \\
(2.45130) \\
{[-0.19735]}\end{array}$ \\
\hline LNER(-2) & $\begin{array}{l}-0.409130 \\
(0.44972) \\
{[-0.90974]}\end{array}$ & $\begin{array}{l}-3.275799 \\
(1.56714) \\
{[-2.09030]}\end{array}$ & $\begin{array}{l}0.034001 \\
(0.43918) \\
{[0.07742]}\end{array}$ & $\begin{array}{l}-0.131155 \\
(1.37697) \\
{[-0.09525]}\end{array}$ & $\begin{array}{l}-5.853273 \\
(4.95763) \\
{[-1.18066]}\end{array}$ & $\begin{array}{l}-3.062867 \\
(4.11892) \\
{[-0.74361]}\end{array}$ & $\begin{array}{l}-2.858561 \\
(3.03869) \\
{[-0.94072]}\end{array}$ \\
\hline LNFDI(-1) & $\begin{array}{l}0.069646 \\
(0.06908) \\
{[1.00817]}\end{array}$ & $\begin{array}{l}0.375508 \\
(0.24073) \\
{[1.55988]}\end{array}$ & $\begin{array}{l}-0.087576 \\
(0.06746) \\
{[-1.29813]}\end{array}$ & $\begin{array}{l}0.181987 \\
(0.21152) \\
{[0.86039]}\end{array}$ & $\begin{array}{l}0.775357 \\
(0.76154) \\
{[1.01814]}\end{array}$ & $\begin{array}{l}-0.095397 \\
(0.63271) \\
{[-0.15078]}\end{array}$ & $\begin{array}{l}0.108841 \\
(0.46677) \\
{[0.23318]}\end{array}$ \\
\hline LNFDI(-2) & $\begin{array}{l}0.072789 \\
(0.04604) \\
{[1.58094]}\end{array}$ & $\begin{array}{l}0.232511 \\
(0.16044) \\
{[1.44920]}\end{array}$ & $\begin{array}{l}0.089249 \\
(0.04496) \\
{[1.98495]}\end{array}$ & $\begin{array}{l}0.331692 \\
(0.14097) \\
{[2.35289]}\end{array}$ & $\begin{array}{l}0.663109 \\
(0.50755) \\
{[1.30648]}\end{array}$ & $\begin{array}{l}-0.666645 \\
(0.42169) \\
{[-1.58090]}\end{array}$ & $\begin{array}{l}-0.439882 \\
(0.31110) \\
{[-1.41398]}\end{array}$ \\
\hline LNGDP(-1) & $\begin{array}{l}-0.027732 \\
(0.13455) \\
{[-0.20611]}\end{array}$ & $\begin{array}{l}-0.240517 \\
(0.46888) \\
{[-0.51296]}\end{array}$ & $\begin{array}{l}0.175556 \\
(0.13140) \\
{[1.33602]}\end{array}$ & $\begin{array}{l}1.940166 \\
(0.41199) \\
{[4.70931]}\end{array}$ & $\begin{array}{l}-0.524849 \\
(1.48331) \\
{[-0.35384]}\end{array}$ & $\begin{array}{l}-0.165824 \\
(1.23237) \\
{[-0.13456]}\end{array}$ & $\begin{array}{l}-0.226590 \\
(0.90917) \\
{[-0.24923]}\end{array}$ \\
\hline LNGDP(-2) & $\begin{array}{l}-0.124554 \\
(0.10468) \\
{[-1.18981]}\end{array}$ & $\begin{array}{l}-0.635886 \\
(0.36479) \\
{[-1.74313]}\end{array}$ & $\begin{array}{l}-0.047680 \\
(0.10223) \\
{[-0.46639]}\end{array}$ & $\begin{array}{l}0.480173 \\
(0.32053) \\
{[1.49808]}\end{array}$ & $\begin{array}{l}-1.143964 \\
(1.15402) \\
{[-0.99128]}\end{array}$ & $\begin{array}{l}0.525994 \\
(0.95879) \\
{[0.54860]}\end{array}$ & $\begin{array}{l}0.155644 \\
(0.70734) \\
{[0.22004]}\end{array}$ \\
\hline LNGOVTEXP(-1) & $\begin{array}{l}0.016530 \\
(0.21042) \\
{[0.07855]}\end{array}$ & $\begin{array}{l}1.369413 \\
(0.73326) \\
{[1.86758]}\end{array}$ & $\begin{array}{l}-0.049858 \\
(0.20549) \\
{[-0.24263]}\end{array}$ & $\begin{array}{l}-1.304631 \\
(0.64428) \\
{[-2.02496]}\end{array}$ & $\begin{array}{l}-0.003071 \\
(2.31965) \\
{[-0.00132]}\end{array}$ & $\begin{array}{l}0.424337 \\
(1.92722) \\
{[0.22018]}\end{array}$ & $\begin{array}{l}0.037127 \\
(1.42178) \\
{[0.02611]}\end{array}$ \\
\hline LNGOVTEXP(-2) & $\begin{array}{l}-0.196715 \\
(0.23921) \\
{[-0.82235]}\end{array}$ & $\begin{array}{l}-0.828638 \\
(0.83358) \\
{[-0.99407]}\end{array}$ & $\begin{array}{l}0.138022 \\
(0.23361) \\
{[0.59083]}\end{array}$ & $\begin{array}{l}-0.647057 \\
(0.73243) \\
{[-0.88344]}\end{array}$ & $\begin{array}{l}-1.756254 \\
(2.63702) \\
{[-0.66600]}\end{array}$ & $\begin{array}{l}-0.066085 \\
(2.19090) \\
{[-0.03016]}\end{array}$ & $\begin{array}{l}-0.640855 \\
(1.61631) \\
{[-0.39649]}\end{array}$ \\
\hline LNGOVTREV(-1) & $\begin{array}{l}-0.067270 \\
(0.24620) \\
{[-0.27324]}\end{array}$ & $\begin{array}{l}-1.658026 \\
(0.85793) \\
{[-1.93259]}\end{array}$ & $\begin{array}{l}-0.062971 \\
(0.24043) \\
{[-0.26191]}\end{array}$ & $\begin{array}{l}1.357214 \\
(0.75382) \\
{[1.80045]}\end{array}$ & $\begin{array}{l}-0.507648 \\
(2.71405) \\
{[-0.18704]}\end{array}$ & $\begin{array}{l}-0.177540 \\
(2.25490) \\
{[-0.07874]}\end{array}$ & $\begin{array}{l}-0.056413 \\
(1.66353) \\
{[-0.03391]}\end{array}$ \\
\hline LNGOVTREV(-2) & $\begin{array}{l}0.056589 \\
(0.25048) \\
{[0.22592]}\end{array}$ & $\begin{array}{l}-0.348361 \\
(0.87286) \\
{[-0.39910]}\end{array}$ & $\begin{array}{l}0.006830 \\
(0.24461) \\
{[0.02792]}\end{array}$ & $\begin{array}{l}1.149006 \\
(0.76694) \\
{[1.49817]}\end{array}$ & $\begin{array}{l}-0.357072 \\
(2.76128) \\
{[-0.12931]}\end{array}$ & $\begin{array}{l}0.553918 \\
(2.29414) \\
{[0.24145]}\end{array}$ & $\begin{array}{l}0.717060 \\
(1.69247) \\
{[0.42368]}\end{array}$ \\
\hline $\mathrm{C}$ & $\begin{array}{l}3.036453 \\
(4.33905) \\
{[0.69980]}\end{array}$ & $\begin{array}{l}30.70488 \\
(15.1203) \\
{[2.03070]}\end{array}$ & $\begin{array}{l}0.897435 \\
(4.23740) \\
{[0.21179]}\end{array}$ & $\begin{array}{l}-33.06733 \\
(13.2855) \\
{[-2.48898]}\end{array}$ & $\begin{array}{l}51.65350 \\
(47.8329) \\
{[1.07987]}\end{array}$ & $\begin{array}{l}22.16968 \\
(39.7407) \\
{[0.55786]}\end{array}$ & $\begin{array}{l}27.73367 \\
(29.3183) \\
{[0.94595]}\end{array}$ \\
\hline R-squared & 0.998771 & 0.956790 & 0.996694 & 0.997153 & 0.899510 & 0.945939 & 0.968838 \\
\hline Adj. R-squared & 0.993035 & 0.755145 & 0.981264 & 0.983865 & 0.430554 & 0.693655 & 0.823418 \\
\hline Sum sq. resids & 0.004315 & 0.052402 & 0.004116 & 0.040456 & 0.524418 & 0.361990 & 0.197016 \\
\hline S.E. equation & 0.037927 & 0.132164 & 0.037038 & 0.116126 & 0.418098 & 0.347366 & 0.256266 \\
\hline $\begin{array}{l}\text { F-statistic } \\
\text { Log likelihood }\end{array}$ & $\begin{array}{l}174.1161 \\
49.48268\end{array}$ & $\begin{array}{l}4.744915 \\
27.01177\end{array}$ & $\begin{array}{l}64.59556 \\
49.90940\end{array}$ & $\begin{array}{l}75.04264 \\
29.34040\end{array}$ & $\begin{array}{l}1.918112 \\
6.281643\end{array}$ & $\begin{array}{l}3.749499 \\
9.617708\end{array}$ & $\begin{array}{l}6.662307 \\
15.09267\end{array}$ \\
\hline Akaike AIC & -3.831409 & -1.334641 & -3.878822 & -1.593378 & 0.968706 & 0.598032 & -0.010297 \\
\hline Schwarz SC & -3.089433 & -0.592664 & -3.136846 & -0.851401 & 1.710683 & 1.340009 & 0.731679 \\
\hline Mean dependent & -0.425262 & -2.211563 & 4.187326 & 7.334176 & 1.993769 & 13.87798 & 13.68334 \\
\hline S.D. dependent & 0.454436 & 0.267090 & 0.270589 & 0.914201 & 0.554054 & 0.627599 & 0.609841 \\
\hline $\begin{array}{l}\text { Determinant resid c c } \\
\text { Determinant resid c }\end{array}$ & (dof adj.) & $\begin{array}{l}0.000000 \\
0.000000\end{array}$ & & & & & \\
\hline
\end{tabular}


Table 9. VAR Granger Causality/Block Exogeneity Wald Tests

Sample: 120

Included observations: 18

\begin{tabular}{llll}
\hline \hline \multicolumn{2}{l}{ Dependent variable: LNCPI } & & \\
\hline Excluded & Chi-sq & Df & Prob. \\
\hline LNDR & 0.302263 & 2 & 0.8597 \\
LNER & 0.986930 & 2 & 0.6105 \\
LNFDI & 4.094816 & 2 & 0.1291 \\
LNGDP & 1.420388 & 2 & 0.4915 \\
LNGOVTEXP & 0.723301 & 2 & 0.6965 \\
LNGOVTREV & 0.128913 & 2 & 0.9376 \\
\hline All & 8.993623 & 12 & 0.7035 \\
\hline
\end{tabular}

Dependent variable: LNDR

\begin{tabular}{llll}
\hline \hline Excluded & Chi-sq & Df & Prob. \\
\hline \hline LNCPI & 3.963605 & 2 & 0.1378 \\
LNER & 4.964937 & 2 & 0.0835 \\
LNFDI & 5.343960 & 2 & 0.0691 \\
LNGDP & 3.051937 & 2 & 0.2174 \\
LNGOVTEXP & 3.629110 & 2 & 0.1629 \\
LNGOVTREV & 3.857518 & 2 & 0.1453 \\
\hline All & 20.13458 & 12 & 0.0646 \\
\hline
\end{tabular}

Dependent variable: LNER

\begin{tabular}{llll}
\hline \hline Excluded & Chi-sq & Df & Prob. \\
\hline \hline LNCPI & 3.559977 & 2 & 0.1686 \\
LNDR & 0.942310 & 2 & 0.6243 \\
LNFDI & 4.956445 & 2 & 0.0839 \\
LNGDP & 2.415904 & 2 & 0.2988 \\
LNGOVTEXP & 0.350880 & 2 & 0.8391 \\
LNGOVTREV & 0.069792 & 2 & 0.9657 \\
\hline All & 34.75194 & 12 & 0.0005 \\
\hline
\end{tabular}

Dependent variable: LNFDI

\begin{tabular}{llll}
\hline \hline Excluded & Chi-sq & Df & Prob. \\
\hline \hline LNCPI & 18.02387 & 2 & 0.0001 \\
LNDR & 19.35958 & 2 & 0.0001 \\
LNER & 23.76842 & 2 & 0.0000 \\
LNGDP & 22.36107 & 2 & 0.0000 \\
LNGOVTEXP & 6.924919 & 2 & 0.0314 \\
LNGOVTREV & 5.352695 & 2 & 0.0688 \\
\hline All & 138.4396 & 12 & 0.0000 \\
\hline
\end{tabular}

Dependent variable: LNGDP

\begin{tabular}{llll}
\hline \hline Excluded & Chi-sq & Df & Prob. \\
\hline \hline LNCPI & 1.099329 & 2 & 0.5771 \\
LNDR & 0.103676 & 2 & 0.9495 \\
LNER & 1.396643 & 2 & 0.4974 \\
LNFDI & 3.222261 & 2 & 0.1997 \\
LNGOVTEXP & 0.503483 & 2 & 0.7774 \\
LNGOVTREV & 0.050513 & 2 & 0.9751 \\
\hline All & 10.82005 & 12 & 0.5444 \\
\hline
\end{tabular}


Dependent variable: LNGOVTEXP

\begin{tabular}{llll}
\hline \hline Excluded & Chi-sq & Df & Prob. \\
\hline \hline LNCPI & 0.784470 & 2 & 0.6755 \\
LNDR & 1.817275 & 2 & 0.4031 \\
LNER & 0.867480 & 2 & 0.6481 \\
LNFDI & 2.655765 & 2 & 0.2650 \\
LNGDP & 0.372603 & 2 & 0.8300 \\
LNGOVTREV & 0.065504 & 2 & 0.9678 \\
\hline All & 14.41591 & 12 & 0.2749 \\
\hline
\end{tabular}

Dependent variable: LNGOVTREV

\begin{tabular}{llll}
\hline \hline Excluded & Chi-sq & Df & Prob. \\
\hline \hline LNCPI & 1.628326 & 2 & 0.4430 \\
LNDR & 1.924775 & 2 & 0.3820 \\
LNER & 1.131877 & 2 & 0.5678 \\
LNFDI & 1.999668 & 2 & 0.3679 \\
LNGDP & 0.143265 & 2 & 0.9309 \\
LNGOVTEXP & 0.170917 & 2 & 0.9181 \\
\hline All & 14.88606 & 12 & 0.2477 \\
\hline
\end{tabular}

